\title{
QUESTIONS OF NOMENCLATURE
}

\section{Carinopelta nom. nov. and Carinopeltidae nom. nov.- New Substitute Names for a Genus and Family of Cambrian Gastropods}

\author{
P. Yu. Parkhaev \\ Borissiak Paleontological Institute, Russian Academy of Sciences, Profsoyuznaya ul. 123, Moscow, 117997 Russia \\ e-mail: pparkh@paleo.ru \\ Received January 21, 2013
}

DOI: $10.1134 / \mathrm{S} 0031030113040151$

Trilobella Vassiljeva, 1990, a generic name of Cambrian mollusks, is twice preoccupied by the names Trilobella Woodward, 1924 and Trilobella Ivanova, 1955. To eliminate this homonymy, Vassiljeva (1998, p. 75) introduced a new substitute name Igarkiella. However, it turns out that the new generic name is also preoccupied by the trilobite genus Igarkiella Rozova, 1964 (Rozova, 1964, p. 40). In accordance with the ICZN (Art. 60.3) I introduce here a new substitute name Carinopelta nom. nov. (type species Trilobella levis Vassiljeva, 1990) for the genus Igarkiella Vassiljeva, 1998 (=Trilobella Vassiljeva, 1990). The generic name comes from the Latin carina (keel) and pelta (oval Thracian shield).

Since the name of the type genus Igarkiella Vassiljeva, 1998 of the family Igarkiellidae Parkhaev, 2001 (Parkhaev, 2001, p. 161) is a junior homonym of Igarkiella Rozova, 1964, the family name Igarkiellidae is invalid. In accordance with the ICZN (Art. 39) I introduce here a new substitute name Carinopeltidae, based on the type genus Carinopelta nom. nov., a new substitute name for the genus Igarkiella.

\section{ACKNOWLEDGMENTS}

I am grateful to Yu.Ya. Shabanov (Siberian Research Institute of Geology, Geophysics, and Mineral Resources (SNIIGGiMS), Novosibirsk) for drawing my attention to the homonymy between the names of the mollusk Igarkiella and the trilobite genus.

\section{REFERENCES}

International Code of Zoological Nomenclature. Fourth Edition. London: The International Trust for Zoological Nomenclature, 1999.

Parkhaev, P.Yu., Molluscs and siphonoconchs, in Gravestock, D.I., Alexander, E.M., Demidenko, Y.E., Esakova, N.V., Holmer, L.E., Jago, J.B., Lin Tianrui, Melnikova, L.M., Parkhaev, P.Y., Rozanov, A.Y., Ushatinskaya, G.T., Zang Wenlong, Zhegallo, E.A., and Zhuravlev, A.Y., The Cambrian biostratigraphy of the Stansbury Basin, South Australia, Tr. Paleontol. Inst., vol. 282, Alexander, E.M., Ed., Moscow: Nauka/Interperiodica, 2001, pp. 133-210.

Rozova, A.V., Biostratigrafiya i opisanie trilobitov srednego $i$ verkhnego kembriya severo-zapada Sibirskoi platformy (Biostratigraphy and description of trilobites of the Middle and Upper Cambrian of the northwestern Siberian platform), Moscow: Nauka, 1964.

Vassiljeva, N.I., Melkaya rakovinnaya fauna i biostratigrafiya nizhnego kembriya Sibirskoi platformy (Small shelly fauna and biostratigraphy of the Lower Cambrian of the Siberian platform), St. Petersburg: Vses. Nauchno-Issled. Geologorazved. Inst. (VNIGRI), 1998.

Translated by P. Parkhaev 